\title{
Quality Evaluation of Coffee-Like Beverage from Date Seeds (Phoenix dactylifera, L.)
}

Sami Ghnimi*, Raisa Almansoori, Baboucarr Jobe, Hassan MH and Kamal-Eldin A

Department of Food Science, College of Food and Agriculture, United Arab Emirates University

\begin{abstract}
Quality characteristics of coffee-like beverage from roasted date seeds (Phoenix dactylifera, L.) were determined and compared with those of traditional Arabic coffee. The date seed beverage was found to have lower amount of total phenolic compounds and to be a less powerful antioxidant than Arabic coffee. Phytochemical screening showed that date seed extracts contained steroids, tannins, and coumarins, while caffeine, terponoids, saponins, alkaloids, anthraquinones, and anthocyanins were not detected. The levels of trace elements in the date seed extracts were within the ranges reported for Arabic coffee with the exception of cadmium (0.16-0.42 compared to $<0.1$ in Arabic coffee). The sensory evaluation revealed that the date seed extracts were acceptable but were slightly lower in quality compared to Arabic coffee. The date seed extracts were lighter in color, less cloudy, less bitter, and have less coffee flavor compared to the reference Arabic coffee. Before roasted date seed extracts will be approved for human consumption, their possible estrogenic effects need to be evaluated.
\end{abstract}

Keywords: Date seeds; Phoenix dactylifra, L.; Coffee-like beverage; Caffeine-free; Arabic coffee

\section{Introduction}

Fruits of date palm tree (Phoenix dactylifera, L.) are widely consumed in the Middle East and North Africa (MENA) where they play an important role in the nutrition and socioeconomic activities of the people. Date production in the MENA region amounts to 4,878,449 metric tons and in UAE to 900,000 metric tons [1]. The fruit of the date palm, considered a staple food in some countries, is composed of a fleshy pericarp (85-90\%) and a seed (10\%-15\%) [2]. The utilization of date fruits and its waste is very important to date cultivation and to increase income to the sector [3]. The date seed is considered a waste product of many date processing plants producing pitted dates, date syrup and date confectioneries. At present, seeds are used mainly as animal feeds by the cattle, sheep, camel, and poultry industries. Roasted and powdered date seeds are used by some rural communities as coffee substitutes and coffee-like preparations made from date seeds are available in some Arabian markets in the Kingdom of Saudi Arabia (KSA) and United Arab Emirates (UAE). Since coffee drinking is a popular practice in the Arabian region where dates are widely grown, it was postulated that roasting date seeds into coffee-like beverage could represent an alternative product for those who want to enjoy the characteristic flavor and aroma of coffee without raising caffeine intake level. Cohen et al. [4] described and patented a roasting process of three different types of interventions resulting in the making of products that look like coffee in taste and texture. In these interventions, the date kernels were subjected to different types of roasting regime ranging from $150-300^{\circ} \mathrm{C}$. However, information regarding the safety, physical and chemical characteristics of roasted date seed extracts are not available.

Although the chemical and physical changes occurring during date seed roasting are not fully described, it is logical to postulate that some of these changes may be similar to what is happening in coffee roasting. Coffee roasting is an interesting thermal process in which final characteristic flavor and aroma are developed due to complex chemical reactions occurring during roasting. Franca et al. [5] divided roasting process of coffee beans into three successive stages: (i) drying, (ii) roasting or pyrolysis, and (iii) cooling. The drying phase is characterized by slow release of water and volatiles substances and bean color changes from green to yellow. Pyrolysis occurs in the second stage, resulting in complex physical and chemical changes in the beans. This stage is associated with release of $\mathrm{CO}_{2}$, water and volatile substances and the color of beans become brown as a result of caramelization and Maillard reactions. If the roasting process is not halted, beans will burn and therefore cooling is necessary to terminate these reactions [6].

The evaluation of the competitiveness of Arabian coffee alternatives/ substitutes depends on the economy of their production, their sensory acceptability and safety. Sensory evaluation, a critical component to this process, is important in generating new product ideas and improving existing products [7]. Safety is the other most important aspect that should be evaluated especially for hitherto unexploited food raw materials. In the case of date seeds, phytochemical screening including phenolic contents and analysis of caffeine and metal elements are necessary. The objectives of this study were to (i) describe the changes in color, $\mathrm{pH}$, and acidity that occur during roasting of date seeds, (ii) evaluate the sensory attributes of date seed extracts and compare them with traditional Arabic coffee, and (iii) evaluate the safety of the roasted date seed extracts with respect to phytochemical components including phenolic compounds, caffeine, and metal elements.

\section{Materials and Methods}

\section{Raw date seeds characterization}

Fifteen kilograms of seed samples from each of the three date varieties (Khalas, Khunaizy and Fard) were supplied by Al Foah Company (Al-Saad, UAE). The seeds were manually separated from date fruits, thoroughly washed with normal tap water and then with distilled water to remove the adhering dirt, and finally dried in an oven set at

*Corresonding author: Sami Ghnimi, Department of Food Science, College of Food and Agriculture, United Arab Emirates University, P.O. Box 15551, Al-Ain, UAE Tel: 971-03-713-6559, Fax: 971-03-767-5336; Email: sami_ghnimi@uaeu.ac.ae

Received October 13, 2015; Accepted November 05, 2015; Published November 12, 2015

Citation: Ghnimi S, Almansoori R, Jobe B, Hassan MH, Kamal-Eldin A (2015) Quality Evaluation of Coffee-Like Beverage from Date Seeds (Phoenix dactylifera, L.). J Food Process Technol 6: 525. doi:10.4172/2157-7110.1000525

Copyright: $\odot 2015 \mathrm{Ghnimi} \mathrm{S,} \mathrm{et} \mathrm{al.} \mathrm{This} \mathrm{is} \mathrm{an} \mathrm{open-access} \mathrm{article} \mathrm{distributed} \mathrm{unde}$ the terms of the Creative Commons Attribution License, which permits unrestricted use, distribution, and reproduction in any medium, provided the original author and source are credited. 
$80^{\circ} \mathrm{C}$ for 8 hours. Date seeds from these three varieties were weighed, their lengths and diameters were measured by a Vernier caliber, volumes were determined by mixing with poppy seeds in a measuring cylinder, and their densities were calculated as weight/volume. The hardness of the seeds was determined by a Vickers surface micro-hardness device (HMV 2000; Shimadzu, Kyoto, Japan) using $50 \mathrm{~g}$ load for 15 seconds to determine the Vickers hardness number (HV/50). This test uses a microscope to measure the depression caused by a diamond indenter with a load of kilograms on a polished surface and determines HV as the force divided by the surface area of the indentation by the following equation:

\section{$\mathrm{HV}=1.854^{\star}\left(\mathrm{F} / \mathrm{d}^{2}\right)$}

With the constant value of 1.854 being calculated from the specific geometry of the indenter; $\mathrm{F}$ is the indentation load in kilograms-force (kgf), and $\mathrm{d}$ is the diagonal of the indentation in millimeter [8]. In this case, kernel hardness was determined as HV/50 with $50 \mathrm{kgf}$ being the load applied for 30 seconds.

\section{Laboratory roasting of date seeds}

Washed and dried date seeds were roasted at $220^{\circ} \mathrm{C}$ for 6 hours and samples were collected to study the changes induced by roasting with respect to color and acidity $/ \mathrm{pH}$. The roasted date seeds were grinded and preserved at $15^{\circ} \mathrm{C}$ until further analysis. The color of the date seed powders were evaluated every $30 \mathrm{~min}$ during roasting by using Hunter Tristimulus colorimeter (Colortec PCM, Clinton, USA). The instrument was standardized against a black and a white tile before sample measurement. Samples of the powder (4-5g) were wrapped in polyethylene plastic wrap folded to form a closed pack in which the samples were evenly spread out. The color parameters $L^{*}, a^{*}, b^{*}$ were evaluated in duplicates.

For the determination of $\mathrm{pH}$ and acidity, the ground roasted date seeds $(1 \mathrm{~g})$ were extracted with $50 \mathrm{ml}$ of boiling distilled water for 2 min using a magnetic stirrer. The extract was centrifuged at $4000 \mathrm{rpm}$ for 5 min. using Sigma 2-16 centrifuge (Sigma labrzentrifugen D-37620 Osterode am Harz, Germany). The $\mathrm{pH}$ of the extract was determined using an electronic pH meter (Crison, model Micro pH 2002, SA, Barcelona, Spain). The titratable acidity was determined by titrating 10 $\mathrm{ml}$ of extract against $0.01 \mathrm{~N}$ sodium hydroxide using phenolphthalein as an indicator and the results were expressed as a percentage of citric acid.

\section{Safety evaluation of commercial roasted date seed coffee alternatives}

Three commercial roasted date seed powders (coffee alternatives) were purchased from the kingdom of Saudi Arabia (KSA Light and KSA Dark) and from United Arab Emirates (UAE). These powders were analyzed for their elemental composition and they were screened for phytochemicals, phenolic compounds, and caffeine. Elemental analysis determinations of major $(\mathrm{Ca}, \mathrm{K}, \mathrm{Mg}, \mathrm{Na}, \mathrm{P})$ and minor $(\mathrm{Al}, \mathrm{Co}$, $\mathrm{Cu}, \mathrm{Fe}, \mathrm{Mn}$, and $\mathrm{Zn}$ ) trace elements were performed using the Thermo Scientific $^{\text {Tw }}$ iCAP $Q^{\text {re }}$ ICP-MS in a single operation mode. A Thermo Scientific $^{\text {rix }}$ Dionex $^{\text {tix }}$ ICS-5000 was coupled to the iCAP Q ICP-MS for these determinations. The roasted date seed powders were extracted by boiling in water at a ratio of 1:10 (w/v) for phytochemical analyses. The extract was centrifuged and screened for the presence of tannins, terpenoids, saponins, steroids, coumarins, alkaloids, anthraquinones, and anthocyanins according to Yadav et al. [9]. DPPH radical scavenging activity was determined according to the method of Aoshima et al. [10]. Total phenolic contents were determined according to the method used by Singleton and Rossi [11] and ferric reducing antioxidant power (FRAP) was determined in the sample extracts according to method of Iris et al. [12]. Both total phenolic content and FRAP values were expressed as tannic acid equivalents.

For the determination of caffeine, date seed powder $(2 \mathrm{~g})$ was weighed in triplicates and extracted with $100 \mathrm{ml}$ of boiling distilled water for 5 minutes with stirring. The solution was cooled, filtered and $5 \mathrm{ml}$ of the filtrates were diluted to $50 \mathrm{ml}$. Caffeine analysis was conducted as described by Wanyika et al. [13] by high performance liquid chromatography (RP-HPLC) equipped with a 1525 Binary HPLC pump, a 717 plus auto-sampler, and 2487 Dual-absorbance detector (Waters, Miliford, MA, U.S.A). Separation was performed on a reverse phase column Symmetry $(\mathrm{C} 18,250 \times 4.6 \mathrm{~mm}$ i.d., $5 \mu \mathrm{m}$, Waters $)$ at a flow of $1 \mathrm{ml} / \mathrm{min}$. The injection volume was $20 \mu \mathrm{l}$ and the mobile phase was water, methanol, acetic acid (79.9:20:0.1, v/v/v), and the detector was VU set at $278 \mathrm{~nm}$.

\section{Sensory evaluation of commercial roasted date seed coffee alternatives}

A group of 10 trained students were recruited as consumer panelists at the Department of Food Science, United Arab Emirates University, UAE. All sensory work was carried out in the sensory laboratory at the UAE University, which fulfills requirements according to the International Standards (ISO, 1988). A panel of two experts defined the attributes to be evaluated in coffee-like beverages. Panelists were informed and agreed to taste the samples before the tests, and they were informed of the type of product being tested and asked about their coffee consumption habits. Tap water was provided between samples to cleanse the palate. The selected panelists were provided two training sessions to investigate their ability to identify odors and the five basic tastes before the final recruitment.

The sensory properties of the three commercial roasted date seed extracts samples were evaluated and compared to Arabic coffee. Beverage preparations were made from roasted date seed powders and Arabic coffee by boiling $45 \mathrm{~g}$ of the powders in $100 \mathrm{~mL}$ of water for 2 minutes. The sample presentation order was randomized for each panelist. A 15-point hedonic scale was used to quantitate each sensory attribute, where zero indicates the absence of intensity, and fifteen corresponds to an extreme intensity. The attributes evaluated include sourness, bitterness, sweetness, flavor, aroma, cloudiness, color, mouth feel and overall quality.

\section{Statistical analysis}

All experiments were run in triplicate. The experimental data were subjected to Analysis of Variance (ANOVA) and the differences between means were evaluated by Duncan's New Multiple Range Test. Data analysis was performed using a SPSS package (SPSS 14.0 for Windows, SPSS Inc, Chicago, IL, USA).

\section{Results and Discussions}

\section{Date seeds}

The weight, dimensions, density, and hardness data for date seeds from three date varieties are presented in Table 1. Hardness, defined as material resistance to permanent deformation under load, was determined by measuring the Vickers hardness number as HV/50. The values obtained for Khalas, Khunaizy and Fard were 46.5, 45, and 51. Similar to coffee beans, date seeds differ in their hardness with highdensity beans having more cells per cubic millimeter causing a hard 
cell structure. Both dates and coffee kernels contain galactomannan, which is a hard type of fiber $[14,15]$. High density kernels are more resistant to heat during roasting requiring adjustment of the roasting temperature and time and they require stronger milling machines. This is an important aspect when considering seeds from different date varieties for coffee making.

\section{Laboratory roasting of date seeds}

Figure 1 presents the decrease in seed weight during roasting as a result of evaporating water and other volatiles. In all of the three cultivars tested (Khalas, Khunaizy and Fard), there was a reduction in weight of the seed during the first hour of roasting and then the weight became stable as the roasting process continued. The reduction observed here is comparable to the reduction of $13-17 \%$ observed for different types of coffee beans after roasting [16]. The reduction in weight is followed by remarkable changes in the color parameters of the roasted seeds as shown in Figure 2. Prior to roasting, the lightness ( $\mathrm{L}^{*}$ value) of the three varieties averaged around 47 and this value decreased to 15 after 6.5 hours of roasting (Figure 2a), representing 47\% decrease in the original value which indicate progressive darkening of seeds. Roasting increased the red color ( $\mathrm{a}^{*}$ values) as the seeds changed from bright red to dark red (Figure $2 b$ ). On the other hand, a sharp decrease in the $b^{\star}$ values was noticed with prolonged roasting time indicating dark yellow (Figure 2c), which is in agreement with what has been reported in coffee roasting [5]. In the first 30 minutes of roasting, the $\mathrm{pH}$ dropped markedly (Figure 3a) and the titratable acidity increased in all three varieties (Figure $3 \mathrm{~b}$ ) as a result of decreased moisture and possibly due to hydrolysis of some of the organic acids present in the seeds. This observation is similar to what has been reported for coffee beans and explained by the hydrolysis of some amines [16]. After this time, the roasting of the three varieties date seeds was accompanied by a decrease in $\mathrm{pH}$ and increase in titratable acidity possibly due to decomposition

\begin{tabular}{|c|c|c|c|c|c|c|}
\hline Variety & $\begin{array}{l}\text { weight } \\
\text { (g) }\end{array}$ & $\begin{array}{l}\text { length } \\
\text { (cm) }\end{array}$ & $\begin{array}{l}\text { diameter } \\
\text { (cm) }\end{array}$ & $\begin{array}{c}\text { volume } \\
\left(\mathrm{cm}^{3}\right)\end{array}$ & $\begin{array}{l}\text { density } \\
\left(\mathrm{g} / \mathrm{cm}^{3}\right)\end{array}$ & $\begin{array}{c}\text { Hardness } \\
\text { HV/50 }\end{array}$ \\
\hline Khalas & 0.72 & 1.82 & 0.51 & 0.80 & 0.91 & 46.5 \\
\hline Khunaizy & 0.57 & 1.88 & 0.45 & 0.66 & 0.90 & 45 \\
\hline Fard & 0.53 & 1.67 & 0.53 & 0.61 & 0.88 & 51 \\
\hline
\end{tabular}

*Values are means of two determinations. Hardness is reported as Vickers hardness (HV/50) with 50 being the load used in kilograms-force (kgf).

Table 1: Dimensions and hardness of date seeds from three different varieties*

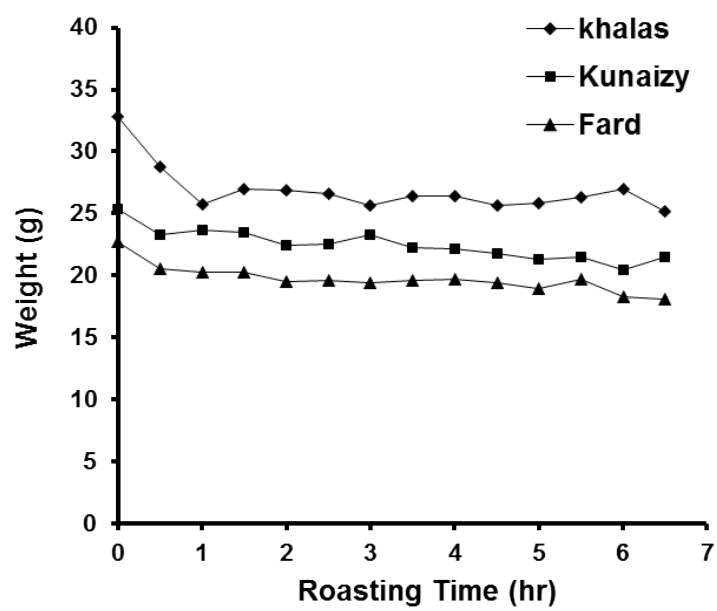

Figure 1: Reduction of weight during roasting of three date seed varieties.
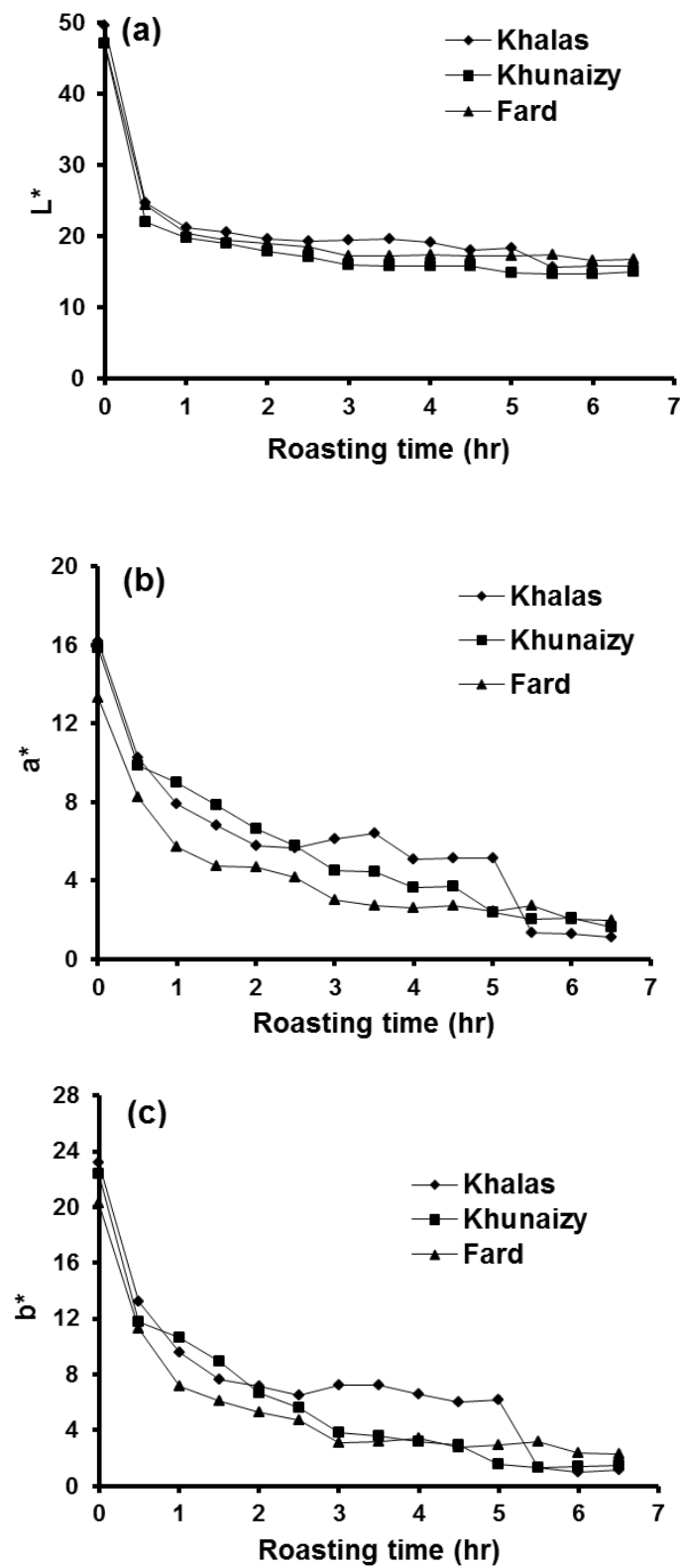

Figure 2: Changes in color parameters $\left(\mathrm{L}^{*}, \mathrm{a}^{*}\right.$ and $\left.\mathrm{b}^{*}\right)$ of date seed extracts.

of some of the organic acids in the seeds.

\section{Safety evaluation of commercial roasted date seed coffee} alternatives

Figure 4 presents photographs of Arabic coffee and three commercial roasted date seed coffee alternatives: KSA light, KSA dark, and UAE as purchased and used for the preparation of beverages tested in this study. In this part of the world, coffee beans are coarsely grinded and are boiled in water to prepare clear beverages; therefore finely milled coffee is not preferred. Table 2 presents the results of elemental analysis of the three commercial roasted date seed powders as compared to ranges found in Arabic coffee. These results show that with the exception of cadmium, the levels found for the selected elements in the date seed powders are within the ranges reported for Arabic 

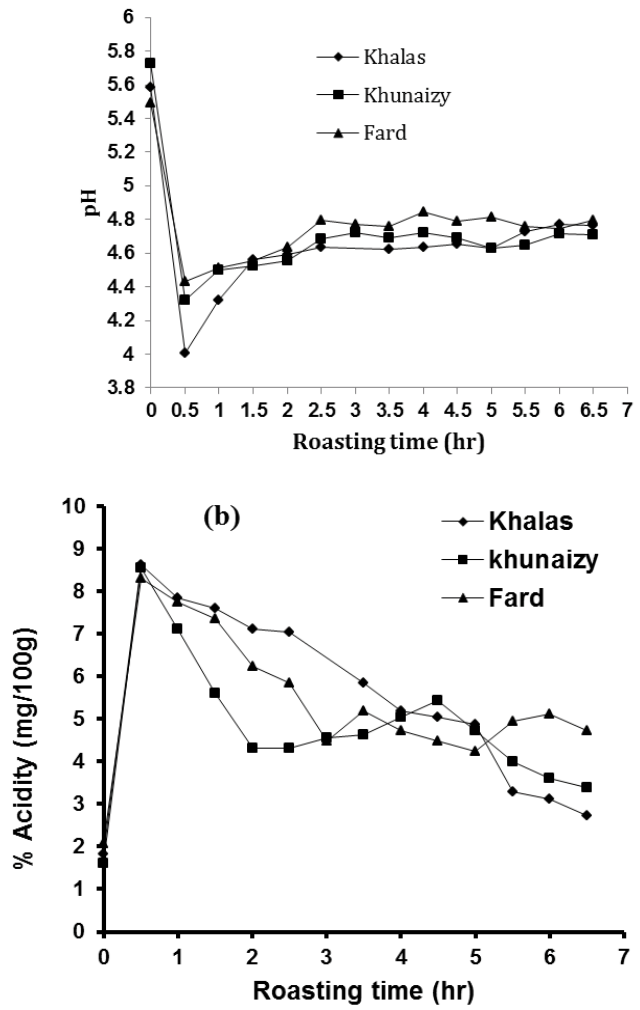

Figure 3: Changes in $\mathrm{pH}$ and acidity during roasting of date seeds.

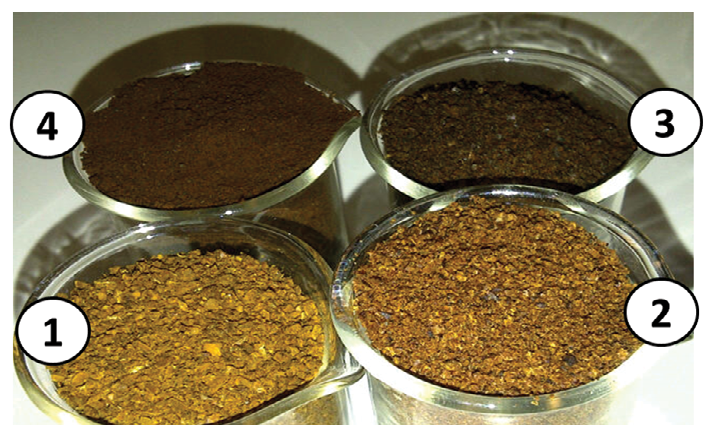

Figure 4: Photographs of (1) Arabic coffee, and three commercial roasted date seed coffee alternatives (2) KSA light, (3) KSA dark, and (4) UAE as coarsely grinded and used for the preparation of beverages tested in this study.

coffee. The higher level of cadmium in date seed powders may be of concern because of the known toxicity of this trace element [17]. The phytochemical screening of the four roasted date seed samples revealed the presence of steroids, tannins, and coumarins, while the other phytochemicals (terpenoids, saponins, alkaloids, anthraquinones, and anthocyanins) were not detected. The presence of steroidal hormones such as estrone in some date seed varieties have been reported $[18,19]$ and the consumption of date seeds was shown to have some effects on sex hormones in animals. For example, Aldhaheri et al. [20] studied the effect of date pits seeds on the testicular and uterus weights and reproductive hormone levels of rats. Although the date seed-containing diet had no significant effects on the weights of the sex organs, it was found that diets containing 12.5 and $25 \%$ date seeds can significantly reduce the oestradiol concentrations in the serum of female rats. This

\begin{tabular}{|l|c|c|c|c|}
\hline Metal & KSA Light & KSA Dark & UAE & Arabian Coffee \\
\hline Sodium & 57 & 54 & 18.7 & $6.6-1467$ \\
\hline Potassium & 2147 & 2167 & 2396 & $11,400-29,100$ \\
\hline Calcium & 356 & 355 & 306 & $490-2200$ \\
\hline Copper & 6.7 & 6.4 & 5.5 & $0.4-30$ \\
\hline Iron & 25.4 & 79.4 & 18.1 & $12-617$ \\
\hline Manganese & 12.4 & 12.6 & 10.6 & $6.6-320$ \\
\hline Zinc & 15.3 & 15.7 & 14.6 & $1.2-803$ \\
\hline Aluminum & 21.2 & 18.5 & 5.0 & $3-200$ \\
\hline Chromium & 0.9 & 9.7 & 1.5 & $0.02-1.3$ \\
\hline Cadmium & 0.42 & 0.19 & 0.16 & $0.001-<0.1$ \\
\hline Lead & $<0.01$ & $<0.01$ & $<0.01$ & $0.021-<2.6$ \\
\hline
\end{tabular}

*Values for roasted date seed powders (KSA light, KSA dark, and UAE) are means of two determinations. The ranges in Arabian coffee were taken from Pohl et al. [28]

Table 2: Concentrations of selected metal elements in three commercial roasted date seed powders compared with ranges in Arabian coffee $(\mathrm{mg} / \mathrm{Kg})^{*}$

effect was attributed to estrogene negative feed-back mechanism on the pituitary and/or hypothalamus level.

The 2,2-diphenyl-1-picrylhydrazyl (DPPH) radical scavenging activity ranged from $65-73 \%$ and was comparable between Arabic coffee and roasted date seed extracts (Table 3). According to the results of the Folin-Ciocalteu assay, the level of total phenolic compounds in Arabic coffee (corresponding to about $2600 \mathrm{mg}$ of tannic acid equivalents $/ 100 \mathrm{~g}$ of powder) is approximately three folds of what have been found in the roasted date seed extracts (Table 3). Similarly, the Arabic coffee recorded the highest value $(8800 \mathrm{mg}$ of tannic acid equivalents $/ 100 \mathrm{~g}$ ) in the ferric ion reducing antioxidant power (FRAP) assay while the roasted date seed extracts have relatively much smaller values. High levels of phenolic compounds in date seeds were reported before ranging 3100-4400 mg gallic acid equivalents/ $100 \mathrm{~g}$ and 580-930 $\mu \mathrm{M}$ Trolox Equivalents Antioxidant Activity (TEAC) [21]. In this study, the difference in total phenolic responses between Arabic coffee and roasted date seed extracts may be due to the higher content or higher extractability from coffee beans compared to date seeds. Recently, it was shown that the phenolic compounds in date seeds belong mainly to the proanthocyanidins, condensed tannins with limited extractability [22]. High levels of phenolic compounds can have beneficial effects by acting as antioxidants or anti-nutritional effects by acting as metal scavengers reducing the bioavailability of iron and by acting as phytoestrogens. Therefore, these results should be interpreted with care especially in communities drinking high amounts of coffee/coffee alternatives.

Figure 5 presents an overlay of a chromatogram of standard caffeine solution and extracts from roasted date seed powder showing an absence of the caffeine peak in the roasted date seed extracts. The absence of caffeine in roasted date seed extract is an advantage for consumers who have considerable concern with caffeine. It has been reported that healthy adults may benefit from taking a small amount of caffeine by increasing alertness or ability to concentrate. However, some people depending on their physiological conditions are more sensitive to caffeine and for them; a small amount could cause reduced sleep, headaches, irritability and nervousness. Health Canada [23] recommended that women of child-bearing age and children should reduce their caffeine intake while healthy adults should consume no more than $400 \mathrm{mg}$ per day. For the Food and Drug Administration of the United State of America, the 1981 recommendation limits maximum daily caffeine intake during pregnancy at $300 \mathrm{mg}$ [24]. In the United Kingdom, the most recent recommendation of the British 


\begin{tabular}{|l|c|c|c|c|}
\hline & KSA Light & KSA Dark & UAE & Arabic Coffee \\
\hline $\begin{array}{l}\text { TPC (g of Tannic Acid } \\
\text { equiv./100g of sample) }\end{array}$ & $0.65 \pm 0.06^{\mathrm{a}}$ & $0.82 \pm 0.01^{\mathrm{b}}$ & $0.50 \pm 0.06^{\mathrm{c}}$ & $2.53 \pm 0.04^{\mathrm{d}}$ \\
\hline $\begin{array}{l}\text { FRAP (g of Tannic Acid } \\
\text { equiv./100g of Sample) }\end{array}$ & $2.91 \pm 0.01^{\mathrm{a}}$ & $3.03 \pm 0.13^{\mathrm{b}}$ & $1.99 \pm 0.10^{\mathrm{b}}$ & $8.87 \pm 0.20^{\mathrm{c}}$ \\
\hline $\begin{array}{l}\text { DPPH (\% reduction in } \\
\text { absorbance) }\end{array}$ & $70.4 \pm 1.9^{\mathrm{a}}$ & $71.1 \pm 2.4^{\mathrm{a}}$ & $64.9 \pm 3.0^{\mathrm{a}}$ & $73.0 \pm 2.0^{\mathrm{a}}$ \\
\hline
\end{tabular}

*Values are Mean \pm SD of three determinations. Means within the same raw having different superscripts are significantly different at $p \leq 0.05$

Table 3: Total phenolic content (TPC), Ferric reducing antioxidant power (FRAP), and 2,2-diphenyl-1-picrylhydrazyl (DPPH) radical scavenging activity of roasted date seed extracts and Arabic coffee. ${ }^{*}$

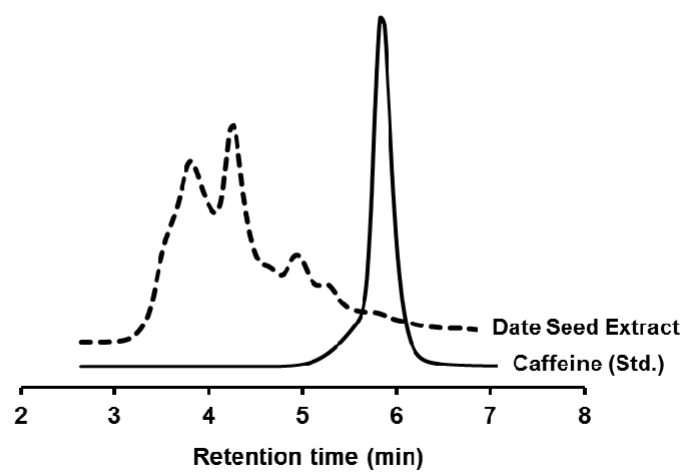

Figure 5: HPLC chromatogram showing the absence of caffeine in roasted date seed extracts with reference to caffeine standard (Detection: $278 \mathrm{~nm}$ ).

Food Standard Agency limits intake to $200 \mathrm{mg}$ per day [25]. During pregnancy, caffeine is easily transmitted through the placenta to the fetus and by virtue of its immature liver the fetus is unable to metabolize caffeine effectively [26].

\section{Sensory evaluation of commercial roasted date seed coffee alternatives}

Consumers' affective test, such as the test run in this study, provides useful information on an existing product characteristics or the future commercial potential of a new developed food by quantifying its consumer preference or degree of liking/disliking [27]. The response of sensory panel for the three commercial roasted date seed extracts (KSA dark, KSA light and UAE) in comparison to Arabic coffee are presented in Table 4. There were significant differences $(\mathrm{p}<0.05)$ in color, cloudiness, bitterness, coffee flavor and overall quality between commercial roasted date seed extracts compared to Arabic coffee. Commercial date seed extracts are lighter in color, and have less cloudiness, bitterness, coffee flavor and overall quality compared to the Arabic coffee. With respect to the intensity of roasted aroma and sourness, the commercial roasted date seed extracts were comparable to Arabic coffee $[13,27,28]$. Roasted date seed extracts may be improved by altered production technique(s) and /or by addition of spices to induce better taste and higher nutritional and health benefits.

\section{Conclusions}

The physical, chemical, sensory and safety attributes of coffeelike product from roasted date seeds were evaluated in this study. The determined attributes allowed comparison between coffee-like beverages and traditional Arabic coffee. The phytochemical screening revealed the presence of steroids, tannins, coumarins, while caffeine, terponoids, saponins, alkaloids, anthraquinones, and anthocyanins

\begin{tabular}{|l|c|c|c|c|}
\hline Attribute & KSA Light & KSA Dark & UAE & Arabic Coffee \\
\hline Color & $4.0 \pm 1.4^{\mathrm{a}}$ & $4.7 \pm 1.5^{\mathrm{ab}}$ & $5.5 \pm 1.3^{\mathrm{b}}$ & $7.7 \pm 2.2^{\mathrm{c}}$ \\
\hline Cloudiness & $7.7 \pm 2.3^{\mathrm{a}}$ & $8.2 \pm 1.7^{\mathrm{ab}}$ & $9.4 \pm 1.7^{\mathrm{b}}$ & $10.7 \pm 1.3^{\mathrm{c}}$ \\
\hline Roasted aroma & $6.5 \pm 1.7^{\mathrm{a}}$ & $5.6 \pm 1.8^{\mathrm{a}}$ & $6.3 \pm 2.1^{\mathrm{a}}$ & $6.8 \pm 2.3^{\mathrm{a}}$ \\
\hline Sourness & $1.1 \pm 0.9^{\mathrm{a}}$ & $1.4 \pm 0.6^{\mathrm{a}}$ & $0.8 \pm 0.8^{\mathrm{a}}$ & $2.2 \pm 2.1^{\mathrm{a}}$ \\
\hline Bitterness & $6.6 \pm 2.7^{\mathrm{a}}$ & $6.6 \pm 3.0^{\mathrm{a}}$ & $5.6 \pm 2.5^{\mathrm{a}}$ & $8.9 \pm 2.8^{\mathrm{b}}$ \\
\hline Coffee flavor & $7.7 \pm 2.5^{\mathrm{a}}$ & $7.1 \pm 2.6^{\mathrm{a}}$ & $7.1 \pm 2.3^{\mathrm{a}}$ & $9.9 \pm 2.0^{\mathrm{b}}$ \\
\hline Overall quality & $7.8 \pm 2.1^{\mathrm{a}}$ & $9.3 \pm 1.6^{\mathrm{ab}}$ & $8.7 \pm 2.0^{\mathrm{a}}$ & $10.9 \pm 2.2^{\mathrm{b}}$ \\
\hline
\end{tabular}

${ }^{*} \mathrm{~A} 15-\mathrm{cm}$ hedonic scale was used, where zero indicates the absence of intensity, and fifteen corresponds to an extreme intensity. Values are Mean \pm SD of records by 10 panelists. Means within the same raw having different superscripts are significantly different at $p \leq 0.05$

Table 4: Sensory score of the three commercial roasted date seed coffee alternatives compared to a sample of Arabic coffee.*

were not detected in the roasted date extracts. The presence of estrogenic compounds is a serious issue that needs to be investigated before date seed extracts can be recommended for human consumption. The absence of caffeine and the high levels of total phenolic compounds in the date seed extracts can serve as a strong motivating factor for those individuals who want to enjoy characteristic flavor of coffee without raising daily caffeine intake. The information obtained from elements analysis reveals that, with exception of cadmium, the levels in the date seed extracts are within the ranges reported for Arabic coffee. The sensory evaluation revealed that date seed extracts are acceptable and only slightly lower in quality compared to Arabic coffee. Therefore, future process of making coffee-like beverages from date seeds may be improved and other additives may be tested to improve the overall quality of the product.

\section{Acknowledgement}

The authors are grateful to Al Foah Company (Alsaad, AbuDhabi, UAE) for supplying the roasted date seeds and for Felix Guiabar Labata for performing the elemental analysis.

\section{References}

1. Food and Agriculture Organization FAO (2012) Crop production and trade data.

2. Hussein AS, Alhadrami GA, Khalil YH (1998) The use of dates and date pits in broiler starter and finisher diets. Bioresource Technology 66: 219-223.

3. Kamal-Eldin A, Hashim BI, Mohammed OI (2012) Processing and utilization of palm dates Fruits for edible application. Recent Patents on Food, Nutrition \& Agriculture 4: 78-86.

4. Cohen S, Givataim H, Herzelia M, Shimshit G (2011) Date kernel preparation Patent number US 2011/0143001A1.

5. Franca AS, Mendonca JCF, Oliveira SD (2005) Composition of green and roasted coffees of different cup qualities. Lebensmittel-Wissenschaft \& Technologie 38: 709-715

6. Sivetz M, Desrosier NW (1979) Coffee technology. Avi Publishing Company

7. Sidel JL, Stone H (1993) The role of sensory evaluation in the food industry. Food Quality Preference 4: 65-73.

8. Craig JR, Vaughan DJ (1994) Quantitative Methods: Micro-indentation Hardness in Ore Microscopy and Ore Petrography. John Wiley \& Sons Inc, New York, USA.

9. Yadav M, Chatterji S, Gupta SK, Watal G (2014) Preliminary phytochemical screening of six medicinal plants used in traditional medicine. International Journal of Pharmacy and Pharmaceutical Sciences 6: 539-542.

10. Aoshima H, Hideaki T, Hirofumi K, Yoshinobu K (2004) Aging of Wiskey increases 1, 1-Diphenyl-2-picryl hydrozyl Radical Scavenging Activity. Journal of Agricultural Food Chemistry 52: 5240-5244.

11. Singleton VL, Rossi JA (1965) Colorimetry of total phenolics with phosphomolybdic- phosphotungstic acid reagent. American Journal of Enology and Viticulture 16: 144-158. 
Citation: Ghnimi S, Almansoori R, Jobe B, Hassan MH, Kamal-Eldin A (2015) Quality Evaluation of Coffee-Like Beverage from Date Seeds (Phoenix dactylifera, L.). J Food Process Technol 6: 525. doi:10.4172/2157-7110.1000525

12. Iris F, Benzie F, Strain JJ (1999) Ferric reducing/antioxidant power assay: Direct measure of total antioxidant activity of biological fluids and modified version for simultaneous measurement of total antioxidant power and ascorbic acid concentration. Methods in Enzymology 299: 15-27.

13. Wanyika HN, Gatebe EG, Gitu LM, Ngumba EK, Maritim CW, et al. (2010) Determination of caffeine content of tea and instant coffee brands found in the Kenyan market. African Journal of Food Science 4: 353-358.

14. Ishrud O, Zahid M, Zhou H, Pan Y (2001) A water-soluble galactomannan from the seeds of Phoenix dactylifera L. Carbohydrate Research 335: 297-301.

15. Nunes FM, Reis A, Domingues MR, Coimbra MA (2006) Characterization of galactomannan derivatives in roasted coffee beverages. Journal of Agricultural and Food Chemistry 54: 3428-3439.

16. Vasconcelos ALS, Franca AS, Glória MBA, Mendonça JCF (2007)A comparative study of chemical attributes and levels of amines in defective green and roasted coffee beans. Food chemistry 101: 26-32.

17. European Food Safety Authority EFSA (2009) Scientific opinion of the panel on contaminants in the food chain on a request from the European Commission on cadmium in food. European Food Safety Authority Journal 980: 1-139.

18. Elgasim EA, Alyousef YA, Humeida AM (1995) Possible hormonal activity of date pits and flesh fed to meat animals. Food Chemistry 52: 149-152.

19. Heftmann E, Bennett RD (1965) Identification of estrone in date seeds by thin layer chromatography. Naturwissenschaften 52: 431-438
20. Aldhaheri A, Alhadrami G, Aboalnaga N, Wasfi I, Elridi M, et al. (2004) Chemical composition of date pits and reproductive hormonal status of rats fed date pits. Food chemistry 86: 93-97.

21. Larrauri JA, Borroto B, Perdomo U, Tabares $Y$ (1995) Manufacture of a powdered drink containing dietary fibre. Alimentaria 260: 23-25.

22. Habib HM, Platat C, Meudec E, Cheynier V, Ibrahim WH (2014) Polyphenolic compounds in date fruit seed (Phoenix dactylifera): characterization and quantification by using UPLC-DAD-ESI-MS. Journal of the Science of Food and Agriculture 94: 1084-1089.

23. Health Canada (2006) Caffeine

24. Higdon JV, Frei B (2006) Coffee and health: A review of recent human research. Critical Reviews in Food Science and Nutrition 46: 101-123.

25. Food Standards Agency (2008) New caffeine advice for pregnant women.

26. Maslowa E, Bhattacharya S, Lin SW, Michels KB (2011) Caffeine consumption during pregnancy and risk of preterm birth: A meta- analysis. The American Journal of Clinical Nutrition 92: 1120-1130.

27. Trigueros L, Sayas-Barberá E, Pérez-Álvarez JA, Sendra E (2012) Use of date (Phoenix dactylifera L.) blanching water for reconstituting milk powder: Yogurt manufacture. Food Bioproducts and Processing 90: 506-514.

28. Pohl P, Stelmach E, Welna M, Szymczycha-Madeja A (2013) Determination of the elemental composition of coffee using instrumental methods. Food Analytical Methods 6: 598-613. 